\title{
FACTORS INFLUENCING A BUILDING-MATERIAL COMPANY BRAND
}

\author{
ALLIN R. DANGERS \\ GEOFF A. GOLDMAN \\ ggoldman@uj.ac.za \\ Department of Business Management \\ University of Johannesburg
}

\begin{abstract}
A brand represents the essence of the value proposition an organisation extends to the market. It is crucial that brands are nurtured with the goal of trying to establish the brand in a top-of-mind awareness position among consumers. By means of a qualitative case study employing 25 interviews which were analysed by using Grounded Theory coding techniques, the most pertinent factors influencing the Corobrik brand were identified. The greatest challenge facing Corobrik is the growing residential sector. The study highlights how Corobrik has grappled and come to terms with the changing nature of its market, and how it has combined all functional areas, from production to distribution, marketing and finance, in promoting its brand.
\end{abstract}

\section{INTRODUCTION}

A brand is more than a look or a logo; it is a consistent and cohesive accumulation of thoughts and feelings which takes time to develop (Du Plessis, Bothma, Jordaan \& van Heerden, 2003; Koekemoer, 2004). Brands define a unique point of differentiation for a firm's products and services; a real opportunity to 'stand out' (Chaudhuri \& Holbrook, 2001; Palmer, 2001; Stewart, 2005). Brands are as much a way of doing business as they are a reputation or identity (Stewart, 2005; Best, 2006). Brand identities create anticipation in the minds of both the consumers who use the brand and the employees who deliver the product or service. Consumers' attitudes towards brand identity is primarily unconscious, as are the judgements settled in the minds of customers, which help consumers to make choices about products (Dick, Jain \& Richardson, 1997; Jobber, 2004).

Corobrik is a face brick manufacturer that is struggling to differentiate itself from its competitors. For consumers of face bricks (homeowners), all face bricks are perceived as being the same and intermediaries (contractors and distributors) do little to make the consumer aware of the different product offerings available in the market. However, Corobrik realises that it has to try to make the final consumer aware of the brand Corobrik, the products it carries and what it represents. Corobrik product is more expensive than other face bricks due, among other factors, to higher input costs in the manufacturing 
process. For this reason, Corobrik is concerned that the market perceives all face bricks as being the same and are thus reluctant to pay a higher price for Corobrik's product.

\section{AN OVERVIEW OF BRANDING}

Brands have become indispensible to organisations as they help consumers recognise an organisation's product which, in turn, may influence purchasing behaviour (Perrault \& McCarthy, 1996; Dick, et al., 1997; Palmer, 2001). According to Sweeney and Soutar (2001), brands that last are those that adapt to customers' changing needs while remaining true to the strategy, purpose and vision of the organisation. These brands foster familiarity and resonate in the minds and hearts of the market (Vriens \& Ter Hofstede, 2000; Jobber, 2004). The owners of successful brands must ensure a holistic approach to brand management is followed, and that all key role-players participate and promote the brand.

Organisations invest a lot of money and effort into establishing and promoting their brands (Benson \& Kinsella, 2004). Brands are carefully researched and evolve over time. Strong brands will flourish, while those that are weak and ill-defined sink into oblivion. Brands are value triggers; they signify quality, value and service to the consumer (Dick, et al., 1997; Chaudhuri \& Holbrook, 2001; Beneke, 2010). To achieve this, the whole organisation must work together, i.e. production, marketing and sales must be actively engaged in the endeavour. When the logo of a company is worn on corporate clothing, for example, the potential consumer comes into contact with the brand: the people involved, the company and what the brand stands for, states Reilly (2004). Customers thus form an impression of the entire organisation, not only the sales and marketing teams.

Brands create barriers to entry for potential competitors as they command a premium and enjoy unrivalled loyalty among consumers (Boyle, 2007). Furthermore, established brands can help to launch successful product line extensions, facilitate entry into new markets, attract and retain talent and have lower price elasticity. Building a strong brand also involves the making and keeping of promises and earning the trust of consumers. Branding success is dependent on a clear value proposition, consistent delivery, trust and local relevance (Peter \& Olsen, 1993; Dick, et al., 1997; Chaudhuri \& Holbrook, 2001).

One element that differentiates successful brands is that the entire organisation promotes the brand, from the CEO to the sales clerk, from the operations director to the operations team. The organisation must be totally focused on promoting the brand, and everyone involved must understand the relevance of the brand - only then can the organisation build a strong brand (Boyle, 2007; Van der Walt, Cloete \& Visser, 2008). Jooste, Klopper, Berndt and Du Plessis (2002) maintain that it is the responsibility of the organisation to maintain the quality of the product and to create the demand for the product. Product quality is 
the responsibility of the manufacturing team, while the marketing team must create the demand - which implies that these functions need to work in tandem to build the brand.

\section{The impact of the supply chain on branding}

The supply chain can have a marked effect on customers' purchasing behaviour. The operations team must ensure that the supply chain performs adequately and that the brand promise is maintained. Negative purchasing experiences may result in customers being lost, or prospective customers being turned away from the product (Benson \& Kinsella, 2004). Organisations such as Dell, Amazon and Wal-Mart have shown that the supply chain can serve as foundation for a strong brand. However, many others have trouble retaining customers due to poor supply chain performance. Marketing executives need to align the brand promise with the company's fulfilment capabilities, as the supply chain can affect the customer experience and brand perception (Benson \& Kinsella, 2004).

The 'moment of truth' is reached when a brand must deliver on the brand promise (Sweeney \& Soutar, 2001; Benson \& Kinsella, 2004). A customer's perception of the brand will be shattered if the company falls short of the brand promise. A bad 'buying experience' will destroy all the good that the marketing and communications team has achieved, with the result that the brand equity will be diluted. According to Benson and Kinsella (2004), the supply chain must be able to 'keep up', or even 'stay ahead' of the requirements in order to ensure that bad buying experiences do not happen.

\section{COROBRIK: A BRIEF BACKGROUND}

Corobrik is a South African manufacturer of face bricks. It occupies the largest section of the face-brick market in South Africa and has also expanded its operations into other countries within Southern Africa. Corobrik manufactures high quality face-bricks at a premium price. Traditionally, Corobrik catered for government and commercial contracts. Although there were sales to the residential market, this was viewed as negligible and Corobrik did not commit any resources to serving this small segment of their market. However, over time government and commercial contracts started to wane and the residential market started to emerge as an important area for Corobrik. However, Corobrik committed much energy to gaining back the lost government and commercial contracts without paying too much attention to the rapidly growing residential sector.

At present Corobrik has 13 company-owned and 12 alliance factories (a privately owned factory, with Corobrik taking care of sales and marketing). The consumer often asks why the Corobrik product is more expensive than that of many of the competitors, but the price is the result of expensive production processes and the grade of product that is available from the factories. Corobrik carries the ISO (International Standards Organisation) mark at 
many of the factories, and is currently in the process of ensuring that all factories become ISO compliant.

Corobrik Centres were established primarily for the convenience of consumers in reaction to the burgeoning residential market. As an added convenience, consumers can purchase related products, as well as large enough quantities to build a house. Small quantities may be purchased for DIY purposes, and consumers will find expert help from a team of people who have the time and are dedicated to helping the individual, whereas to most factory personnel smaller transactions are not worth their while.

\section{Managing the Corobrik brand}

Corobrik has spent a lot of money over time to ensure that, via personal selling and a marketing process, the government and the commercial sectors are well catered for. This strategy entails having a large sales management team that actively calls on architects and 'specifiers' to ensure that the company's products are specified for use in commercial buildings and for government projects. These specifiers ensure that certain products are used on buildings, mainly for aesthetic reasons, and the contractor often has little choice but to use the product that is specified.

However, in the growing residential sector, consumers themselves decide which products to use for their homes. As spending in terms of commercial and government building projects started to wane, Corobrik was faced with a dilemma and it became apparent that the company had to change tactics in order to gain a portion of the residential market. Corobrik is relatively inexperienced in communicating with the residential sector, a segment of the market they, up to this point, did not care much about.

A face brick is quite an easy product to copy. Rivals try to gain market share by copying Corobrik products, selling similar but inferior products under slightly different names. Rivals have also poached Corobrik staff in order to produce 'look-alike' products which resemble the original Corobrik product so closely that it is difficult for consumers to tell the difference.

A trademark cannot be stamped on a face brick because of its nature; once it is built into the wall, a name on the back cannot be seen. A way must be found to showcase major projects where Corobrik products were used, as this could help create brand awareness over rival offerings. Packaging helps in distinguishing the product and creating brand awareness, but only after the product has been bought and delivered, which is too late to influence prospective customers.

The brand is only at 'recognition' level for many architects, developers and contractors - they only know that there is such a product. Consumers, on the other hand, think that 
Corobrik manufactures most face brick, which results in little differentiation between product offerings. In addition, contractors often use the excuse of inferior workmanship and poor quality products in order not to have to build with face brick. However, the customer does not know that this is simply an excuse.

\section{Corobrik's supply chain}

The supply chain at Corobrik is critical to the success of the business. All involved in the supply chain need to ensure that expectations are met in order to ensure that the brand promise is met. An avenue often overlooked by the marketer is that the operations team, and not only the production staff, has to ensure that the supply chain meets expectations in order to ensure that the brand promise is met. The brand promise is broken if the supply chain does not meet expectations; therefore, as part of the complete business cycle, the brand promise is most important to the marketer. The Corobrik brand must be viewed as fulfilling a need and being beneficial to the consumer's life. High-quality face bricks have an aspirational value; they are regarded as expensive, something only the rich can afford.

The supply chain at Corobrik is intricate and includes many role-players other than transport, clay and coal. The clay needed for brick making is mined and supplied to the factories. Some of the clay comes from the company's own reserves, whereas the rest is transported from reserves elsewhere. The clay is put into steel hoppers and goes through a mixing plant, is extruded, cut, packed on kiln cars and finally fired in a kiln to produce the end product. In this manufacturing process, in addition to clay, the following are needed: coal for the body, gas for the firing process and all the machinery at the factory, such as a kiln, extruders, dryers, computers to control the process, as well as labour. Once the product is manufactured, it is palletised and transported to the end user.

If any of the above-mentioned 'links' of the chain are not performed correctly, the factory cannot produce the products correctly and timeously, leading to the brand promise being broken, which could potentially result in consumers deciding to use another brand. Corobrik has a system to monitor effective service levels and to ensure that the customer is satisfied with the product. The customer service staff at Corobrik compiles a CSI (customerservice index) document on a quarterly basis, which views customers' opinion of the level of service rendered by Corobrik. The information is gained by asking customers to answer five questions, using a scale of 1 to 4 . Any 'non-conformance' is reported to the relevant sales manager, who is expected to correct the problem. If a production problem is identified, the non-conformance is reported to the relevant factory manager for corrective action. Followups are done to ensure that the non-conformance has been successfully dealt with.

In addition, Corobrik also has a claims-handling system. Representatives respond to problems within 48 hours by filling in a claim form to lodge the claim. The claim is discussed 
with the superior and a decision is made, and within 48 hours the outcome of the claim is discussed with the client. If the client is satisfied, the form is signed off. A copy of the form is then sent to the relevant factory, where it is filed for ISO purposes.

\section{PURPOSE OF THE STUDY}

With diminishing commercial and government building contracts, and the emergence of the residential market, Corobrik is concerned that their brand is being perceived as generic. There is no differentiation of the brand and consumers are not aware of the potential benefits of using Corobrik product. Contractors and distributors exacerbate the problem, seeing no reason to explain the benefits of the Corobrik product to the final consumer. They would prefer customers to use cheaper product to enhance the contractors' and distributors' profit margins. The consumer is thus unaware of the benefits of the Corobrik product, and regards the brand as generic; he/she sees no reason to pay more for brick that is not perceived as superior. The crux of the matter, thus, is that brand awareness is very low in the residential face-brick market.

Seen against this backdrop, the following research question can be posed:

\section{What effect does the emergent residential market have on Corobrik?}

From this stated research question, the study aims to ascertain how Corobrik needs to adapt to the demands of an emerging market. This will be done by assessing what the most salient market influences are that impact on the Corobrik brand at present.

\section{RESEARCH STRATEGY}

\section{Research approach}

A qualitative approach was chosen for this study, as it attempts to understand research subjects' actions in terms of their own beliefs, history and context (Babbie \& Mouton, 2004). Furthermore, the design employed in this study was a case study. A case study is an investigation of a single unit (Handel, 1991; Yin, 1994; Babbie \& Mouton, 2004), with a myriad of variables and taking multiple perspectives into account. In this study, the emphasis is on the Corobrik brand, which is affected by a host of factors. The brand will be investigated from multiple perspectives, both internal and external to the company.

\section{Participants}

Care was taken to ensure that the people who were interviewed represented the entire face-brick industry. Therefore architects, developers, distributors, contractors and sales managers were selected on a purposive basis. From each of the groups that represent the face-brick industry (i.e. architects, developers, distributors, contractors and sales managers), five interview subjects were selected on a purposive basis, thus bringing the total sample 
to 25 research subjects. Final consumers, however, were not included in the study. It was felt that those who are involved in the industry would be in the best position to provide meaningful insights about, and comment on, Corobrik, rather than the final consumer of the Corobrik product.

\section{Methods of data gathering}

Unstructured interviews were used as the main method of data collection for this study. Instead of asking direct questions, the interview was a discussion centred on the perception of Corobrik in the marketplace and what should be done to differentiate Corobrik from its competitors. Such data would be difficult to obtain from final consumers, thus providing further justification for the choice of gathering data from the role-players within the facebrick industry. Interviews were recorded and transcribed verbatim to act as source data for later analysis. Field notes were taken during interviews, specifically of non-verbal cues, to further illuminate the context of the interview and to allow for a true representation of what had been discussed.

\section{Procedure}

All the research subjects were familiar to Mr Dangers through his position as National Sales Manager of Corobrik. This facilitated gaining interview subjects' consent to participate in the study and also took care of any potential ethical issues. None of the interview subjects requested a signed statement of ethical intent. Interviews were conducted in neutral settings (such as boardrooms or tea-rooms), or at the interview subjects' offices, and a total of 25 interviews were held. All interviews were completed before analysis commenced. For qualitative research to be deemed of good quality, the trustworthiness thereof needs to be interrogated under the following headings (Lincoln \& Guba, 1985):

- Credibility: Is there compatibility between the constructed realities that exist in the minds of respondents and those that are attributed to them? This study used a large sample and observation was persistent, as there was involvement in recording the interviews, transcribing the data and coding the data. Some research subjects are good acquaintances of AR Dangers, and they acted as member checks to test that intentions were correctly interpreted.

- Transferability: This constitutes the degree to which findings can be applied to other contexts or other respondents. The intention of this study was not to illuminate further than the Corobrik context, so transferability here pertains to how the findings can be extrapolated to the entire population. The sampling strategy followed had exactly this consideration in mind. It was a large sample and strove to be inclusive of all role-players in the industry.

- Dependability: Here, assurance must be sought that applying the research to similar research subjects in similar contexts will produce similar results. In effect, if one can ensure credibility, it ought not to be necessary to prove dependability. 
- Confirmability: This represents the degree to which the findings are the product of the focus of the study and not of bias. Hard-copy interview transcripts, and an exercise book in which notes were made upon which the coding was based, leave a trail of how conclusions, interpretations and recommendations can be traced to their source.

\section{Treatment of the data}

Gathered data was subjected to a variation of Grounded Theory (GT) (as the method of analysis as opposed to design), as it allowed for the reality pertaining to the Corobrik brand to inductively, and iteratively, emerge from the gathered data. The process of GT analysis proposed by Strauss and Corbin (1990) was used in this study, which involves assigning the initial data to a few tentative categories and continually adding new data to them, at the same time interrogating whether the new data fits the parameters of the established categories or whether new categories need to be added (Kendall, 1999). The analytical process involved three rounds of coding. During open coding, all sentences (the designated unit of analysis) were allocated labels. As a consequence every phrase (sentence) of similar meaning received the same label while every 'new meaning' phrase was allocated a new label, and ultimately a series of themes emerged (Babbie \& Mouton, 2004; Henning, Van Rensburg \& Smit, 2004). During axial coding, relations and linkages among these themes were revealed, while selective coding enabled the construction of an essential 'narrative' of the entire dataset as it pertained to the Corobrik brand.

\section{FINDINGS AND RESULTANT DISCUSSION}

After the interviews were conducted, the analytical process yielded a total of 34 categories as a result of the task of open coding. The tasks of axial and selective coding reduced this to seven core categories. These core categories were seen as the most pertinent challenges to the Corobrik brand. These will now be elaborated upon. Please note that in the interest of brevity, only a limited number of annotations have been included as evidence.

\section{Customer education and training}

Interviews revealed that training is deemed crucial for the proper education of consumers, paving contractors, key distributors and Corobrik staff. Training enables the sales staff to provide customers with adequate information on Corobrik products to make an informed decision. It was also evident that consumers were often uninformed about the Corobrik manufacturing process and product quality, and therefore, often based their purchase decisions on price alone. As consumers have no basis of comparison between various manufacturers, price becomes the only consideration. Below are some views expressed in this regard during interviews: 
'Corobrik must educate the consumer and showcase their manufacturing units to show how the product is made. You should inform consumers that the product is ISO compliant, and thus not only better, but also more expensive.'

- Research participant no. 4

'You must communicate more with the end user. They are not educated and know nothing about the technical side of bricks. So more technical information ... so they can make informed decisions. Also, your distribution channel needs to get the message across. But customer education is key ... if you want get them to ask for your product by name. But your own staff needs to be trained better so they can inform customers better and promote the Corobrik brand name.'

- Research participant no. 12

Literature stresses the importance of educating the consumer to prevent misconceptions about the product (De Chematory \& McDonald, in Boyle, 2007). No brand can be successful in its attempt to be regarded as unique by the consumer if proper, well-informed communication does not take place with its target market. Consumers need to know what benefit would be derived from a higher-priced brand (Kotler, 2003; Ballantyne, Warren \& Nobbs, 2005); otherwise price will remain the only basis of the purchasing decision.

\section{Brand awareness}

From the interviews it was apparent that consumers view the Corobrik brand as generic, using the term 'Corobrik' to refer to bricks in general. Interview participants feel that establishing brand awareness (through, inter alia, education) will be a countermeasure to a brand name that has become generic. In this regard, marketing communication efforts are crucial for creating brand awareness among consumers. A host of alternatives is available here, such as clear logos on delivery trucks, decals on palletised cubes of bricks and clear signage at building and construction sites. The following annotations were forthcoming from interviews:

'... brand awareness is key to the success of the company. You must continue to market the product through consumer magazines, and make use of the name at building sites and on trucks, so that customers later ask for it by name. These things influence the consumer, and ensure that the architects also influence the consumer.'

- $\quad$ Research participant no. 7

'Let people in townships ... all over, know about the product by way of radio ... TV ... and signage. Remember, this is a growing market.'

- Research participant no. 20

Literature details the importance of product differentiation as the basis of distinguishing one total product offering from that of competitors. Ideally it should extend beyond differentiation to a state where consumers insist on a particular brand because of the 
intrinsic benefits thereof (Chaudhuri \& Holbrook, 2001; Singh, Hansen \& Gupta, 2005; Siomkos, Vasiliadis \& Lathiras, 2005). Brands live in the minds of consumers, and for the brand to get there involves knowledge of the benefits of the brand and the factors that differentiate it from competitors (Belch \& Belch, 1995; Davis, 2002; Benson \& Kinsella, 2004; Berndt \& Du Toit, 2008). A brand should not be allowed to become generic as this represents the antithesis of what branding tries to achieve. Generic brands are not unique and differentiated, and become commodities which will neither command a premium, nor lead to commitment levels (Grace \& O'Cass, 2002; Du Plessis, et al., 2003).

\section{New product development}

It was evident from the interviews that Corobrik needs to consider brand protection of all its products in order to prevent cloning thereof. One way of doing this is by using the corporate brand as a prefix, such as Corobrik Topaz Travertine, ensuring that competitors are prevented from using the trade name. Interview subjects also reflected on introducing new products such as an 'economic' face brick for the residential sector that is priced correctly to attract new customers, as the following excerpts allude to:

'Look, I don't think you will stop other guys from trying to copy your product ... but maybe you guys should do something different ... maybe ... develop a good quality stock brick for plaster purposes. At times, there are shortages, which hamper the use of face brick as they battle to find an adequate supply of good quality stock bricks. You can't build the "outer skin", if you can't build the "inner skin' because of a shortage of stock bricks.'

- Research participant no. 16

'... has Corobrik considered re-entering the stock brick market in Gauteng? It would help ensure a constant supply of good quality stock bricks, and we sure need that.'

- $\quad$ Research participant no. 3

It is apparent in the literature that new product development has a marked advantage for a company (Cant, Strydom \& Jooste, 1999). Familiarity with a particular brand builds immediate loyalty for the new product from those consumers already loyal to the brand (Davis, 2002; Strydom, Jooste \& Cant, 2004).

\section{Problem solving}

Generally, interviews indicated that not many problems were experienced when dealing with Corobrik. Those research participants who cited problems mentioned that Corobrik needs to be more flexible when attending to demands and complaints from consumers. Problems are encountered with deliveries of large quantities of stock to site and with collections of specific stock from factories. It is felt that Corobrik does not react to the needs of the customer (in this case especially contractors), and that internal processes and procedures are put before the needs and demands of customers, as the following extracts allude to: 
'I think you need to be more flexible when distributors collect bricks from the factories. Sometimes we need the product a.s.a.p., but the factory dispatch people are not sensitive to the needs of contractors.'

- Research participant no. 23

'... deliveries to site are a problem. At times delivery is late, or too many bricks are delivered. Solve the problem there and then, on site, rather than spend huge amounts of time arguing about the problem.'

- $\quad$ Research participant no. 3

The literature advances the notion that fostering good relationships with customers is crucial for customer retention (Chaudhuri \& Holbrook, 2001; Jobber, 2004; Berndt \& du Toit, 2008). This relationship with the customer must be based on trust, consistency and a set of expectations, which also help build the brand of a product (Vriens \& Ter Hofstede, 2000). Strong brands imply competitive standards of delivery that meet or exceed the expectations of the consumer, leading to credibility of the brand (Singleton, 2004; Beneke, 2010). The staff has an active role to play in meeting the brand promise. If brand promises are not met, brand equity will be diluted which can potentially destroy a brand (Vriens \& Ter Hofstede, 2000; Singleton, 2004; Ballantyne, et al., 2005).

\section{Availability of product}

In general, interviews revealed that customers experienced few incidences of Corobrik's product not being available, as the interview extracts below bear witness to. Corobrik's order book, together with the last 12 months' history of orders, drives the production process. At Corobrik, one department alone cannot make decisions on production or production process. The departments concerned meet monthly to ensure that the correct products are made, and if changes are necessary, they are only made after consultation with the Sales and Manufacturing departments. The following statements support these claims:

'Corobrik products are usually available and are delivered as promised. During the past 10 years that I have used Corobrik, I have rarely experienced any problems of this kind.'

- Research participant no. 8

'... availability of product gives Corobrik a competitive edge. And the quality of your product is good. It's all about being able to produce more than the competition, and Corobrik is the biggest.'

- $\quad$ Research participant no.1

Views from the literature seem to converge on the notion that availability of a product is crucial for consumers to maintain brand loyalty, as unavailability (stock-out) will result in consumers switching brands (Perrault \& McCarthy, 2002; Strydom et al., 2004; Van der Walt, et al., 2008). Benson and Kinsella (2004) state that the supply chain is critical in ensuring 
availability of stock. To ensure that stock-outs do not occur, supply chain intermediaries have to supply the required product on time and at the right place, thereby supporting the brand promise (Cant, et al., 1999; Benson \& Kinsella, 2004).

\section{Customer service}

Many interviewees complained of poor customer service with regard to sales procedures, the cash-handling process and the payments procedures, which they feel are antiquated and slow. Internet payments are not accommodated at the centres, and faster, more userfriendly point-of-sale systems could be utilised. The annotations below reiterate these sentiments. Without the backing of the Operational teams, customer service cannot improve, as Operations form an integral part of the team that successfully dispatches between 5 and 6 million bricks per day.

'I think customer service needs work ... through little things like simplifying the ordering process ... I mean ... it's just so ... so ... it's not customer friendly. I sometimes also think the whole buying experience is a bit of a let-down ... but then again, we are talking about bricks here. In any business customer service is a key element and I think Corobrik can improve here.'

- Research participant no.1

'The thing is ... good service levels drive my company and I need good service and better communication from Corobrik. The ordering process with regard to large orders must be explained, and the use of bulk orders made clear. Customers must know how you do things ... and why.'

- Research participant no. 9

It is clear from the literature that service levels are one of the moments of truth of the brand (Hansen \& Christensen, 2003; Benson \& Kinsella, 2004; Boyle, 2007). A good service experience can induce a customer to re-purchase as the product offering meets the expectations of the customer. The ability of the brand to meet the customers' expectation becomes more important than the price of the product (Davis, 2002; Benson \& Kinsella, 2004; Schoenbachler, Gordon \& Aurand, 2004).

Stewart (2005) cautions that the opposite is also applicable, namely that bad service experiences will alienate customers and could even result in negative word-of-mouth publicity. This could even result in negative perceptions of a brand being formed in the minds of potential customers, which could have a serious impact on the longevity of a brand (Grace \& O'Cass, 2002)

\section{Price}

It is clear from the interviews that the face-brick market is one where products are not differentiated and where price is the main consideration, as the following excerpts testify to: 
'... and if your products are too expensive, consumers will not buy the products. No consumers means that your production will go down ... which could cause factories to close. My market needs a well-priced face brick ... Corobrik can charge a slightly higher price, but don't charge a premium. So ... charge a fair but not outrageous price. If your name and your product are good, you have earned the right to charge more, but you must give the client something in return for that.'

- Research participant no. 20

'Price is key. See, I supply developers who build in the "buy-to-let" market, and price is more important than aesthetics. However, Corobrik must be careful not to supply for very low-priced developments, which could hurt the image of Corobrik. Although price is important, products must not be priced too low either, because they can be seen as cheap and nasty. Aim for the higher income groups.'

- $\quad$ Research participant no. 7

Brands are indicators of value and price (Dick, et al., 1997; Benson \& Kinsella, 2004). Brandloyal customers are willing to pay a premium and generate referrals (Davis, 2002; Rowley, 2003; Ballantyne, et al., 2005). A stable customer base is a core business asset, and the benefit of customer loyalty - apart from referrals, which is basically unpaid for marketing communication - is lower price sensitivity (Rowley, 2003).

\section{CONCLUSIONS AND RECOMMENDATIONS}

In terms of the seven key areas identified in the study, the following is pertinent:

- Customer education: Corobrik has to provide education and training, not only to consumers, but also to role-players in the outbound supply chain, to help create a demand for the product. A form of educating the contractors is by organising regular factory visits and presentations, which discuss the benefits of the product, and, furthermore, showcase the manufacturing units. To educate the homeowner, a compact disc could be made that shows the benefits of the product and showcases the manufacturing units. Reaching homeowners in this way could help them recognise the brand, and realise that the Corobrik brand is superior and unique. Another form of customer education could be to provide technical information so that consumers are able to make informed decisions. For this to be successful, the co-operation of the Technical and Operations teams within Corobrik will have to be sought.

- Brand awareness: The brand must become more 'visible'. Truck backs and pallet posters, which are the responsibility of the Operations team at Corobrik, are an important part of the brand-awareness campaign, as trucks can act as 'moving billboards'. Strong brand awareness could lead to brand preference and eventually to brand insistence. Television and radio are the prime media vehicles and although expensive, the cost is negligible compared to the loss if the brand withers into obscurity. Various other methods are available to create brand awareness, such as signage at all major projects, newsprint 
advertising as well as advertorials, and advertising in consumer and trade magazines. This should be done on a consistent basis, in order for the brand to be seen, recognised and preferred.

- New product development: In the current difficult economic climate, an economic face brick is required for the residential sector, especially the town-house market, but also for other affordable housing and even for low-cost housing. For this middle- to lower-end of the market, price is a major concern, and these consumers either are aware only of the cheaper generic products, or decide that the Corobrik brand would be too expensive for them to use. Brand insistence in this market segment is rare, as the main concern is the price of the product. However, if Corobrik could develop an economic face brick, using overburden material or possibly a cheaper source of clay, it is feasible that the price could be reduced. In any event, Corobrik should be flexible in its approach: manufacture an economic face brick for the mass market when the demand is high, and change over to, for example, plaster bricks when demand is low.

- Problem solving: In order to keep the brand promise, Corobrik staff has to attend to any problems consumers might experience in a courteous, timely and effective manner. The Technical and Operations teams need to assist the Sales team to solve any problems to ensure that trust in the brand is maintained. Corobrik must ensure that homeowners and other non-professionals know how to use the products correctly in order to minimise possible problems. There are a number of avenues that can be used to achieve this aim, for instance consumer magazines and instructions on compact disc/video. The consumer should also be made aware of the pitfalls, such as incorrect cleaning methods, when using face brick, as knowing how to use and clean the product correctly will prevent many consumer-related problems. Tile manufacturers print instructions on the box, and Corobrik should consider adopting this method, for instance by using inserts that explain general usage instructions, such as blending, cleaning and correct application of face bricks.

- Availability of product: Consistent availability of product is often the key to a company's success and is an area that the Production-planning department can assist with. If a regular customer continually cannot find the brand owing to stock-outs, he/she will eventually switch brands completely. Many large contractors prefer to deal with Corobrik because large quantities of product are available for larger projects. Corobrik must ensure that the consumer is aware of the company's ability to supply large volumes of product on a continual basis, and the Corobrik centres must be well stocked to showcase this fact. If consumers trust the brand, a buying commitment could follow and this is ultimately what the company wants. Furthermore, it is imperative to inform developers about Corobrik's provisional ordering system, as this is could be a point of competitive advantage, which could lead to brand insistence and customer commitment.

- Customer service: In order to retain customers, good service must be rendered to new as well as existing customers. A product that is faulty is bad enough but inadequate service compounds matters, leading to the brand promise being broken. At Corobrik the 
Operations team is an integral part of good customer service, through timely and correct dispatch, improvement of truck turnaround times and ensuring that the correct product is loaded and delivered every time.

- Price: For the commercial building market, price is less of a concern as often the total price of bricks can be as low as $2-3 \%$ of the total cost of the contract. On the other hand, in the residential sector, the cost of bricks can be as high as $10 \%$ of the total cost. It is clear that the development of an economic face brick is imperative to capture the mass housing market. The development of such an economic face brick would be the duty of the Production team at Corobrik. They must also ensure that a suitable product is produced and that costing remains in line with customer requirements. Furthermore, consumers should be informed of the advantages of using face brick for their homes; they require less maintenance and, therefore, less expensive upkeep. Usually consumers do not take the high cost and extra effort of having their homes repainted every five years into consideration when buying brick. This education can be done in the form of a cost comparison between the various finishes that one can use on a house, and should be highlighted in the major consumer and trade magazines in order to reach contractors as well.

From the findings, it can be seen that Corobrik is experiencing a few pertinent challenges. First, the Corobrik brand has become generic. Corobrik is associated with all face bricks and does not represent a pertinent value proposition or brand promise. This is a troublesome state of affairs for Corobrik, as they want to differentiate themselves from other face-brick manufacturers. However, the question can be posed: Is differentiation necessarily a good strategy to pursue for a face-brick manufacturer? It is apparent that Corobrik has priced itself at a premium, and that might be the crux of the matter. The trend is, as Corobrik itself has realised, that a growing residential market has emerged. This market seems to be price sensitive and views face bricks more as a commodity item.

Corobrik is also grappling with the concept of developing new products for sectors of the market it has not yet tapped into. In this regard, interviews suggest that the company should consider lower-end face bricks and stock bricks. However, Corobrik views itself as a provider of high quality face bricks. Diversifying into other areas of the market will obviously conflict with how Corobrik sees itself and what it stands for as a company. However, in the light of the discussion, maybe Corobrik can stand to gain more through embracing the demands of the growing residential market in its brand promise and, ultimately, overall strategy.

Furthermore, Corobrik realises the effect of supply chain inefficiencies on their business. Here aspects such as availability of the product, customer service and internal processes can - and do - negatively impact on the brand promise extended by Corobrik. It is apparent from the study that Corobrik realises the impact that operations, and the supply chain in 
general, has on the perception of the Corobrik brand. It is noticeable that at Corobrik, the Technical, Operations and Sales teams work closely together to ensure that the Corobrik brand is being promoted all the time. It is in this area that the study has a valuable theoretical contribution to make. Contemporary literature views marketing as the domain responsible for building product and corporate brands. However, this study very pertinently shows that branding spans across different functional areas of a business and that operations and logistics have an equally important role to play in building a brand. This is definitely an area that would facilitate further inquiry.

The domain of business management has become increasingly fragmented over time and this has led to the development of various specific areas of inquiry within the broader ambit of 'business management'. The result is that practitioners and scholars alike become so entrenched in these domains that they lose sight of the bigger picture. A business is an entity where the whole should be greater than the sum of the respective parts. Following this principle of holism, it is therefore only logical that a business and the management thereof should be studied as a holistic entity comprising different parts that function together in a harmonious fashion. It is this principle that this study is trying to promote. Corobrik has shown that promoting the brand depends on more than just the efforts of a marketing and sales team. It is dependent on the whole business, from the production process to the distribution centres, to the packaging around the brick pallets, to the signage on the brick trucks and the signage at building sites.

In turn, the value chain has a crucial role to play in branding, as the Corobrik case indicates, as all the links in the supply chain, as listed above, can be utilised to enhance the brand.

\section{CONCLUDING REMARKS}

The study has pertinently shown that branding is the responsibility of various functional areas within the organisation. In this case, Corobrik sees branding as the responsibility of Marketing and Sales, Operations and the Technical (Operations) areas. Of concern, however, is the changing nature of Corobrik's market. The growing residential sector of their market has reduced Corobrik to a generic brand. Although Corobrik still sees itself as a premium brand within the industry, the shift in the market is making it necessary for them to rethink their conventional approach to doing business. 


\section{REFERENCES}

Babbie, E. \& Mouton, J. 2004. The practice of social research. Cape Town: Oxford University Press.

Ballantyne R., Warren A. \& Nobbs K. 2005. The evolution of brand choice. Brand Management, 13(4/5):339-52.

Belch, G.E. \& Belch M.A. 1995. Introduction to Advertising and Promotion: An Integrated Marketing Communications Perspective. Irwin: Boston.

Beneke, J. 2010. Towards a conceptual model - an investigation into the propensity of the emerging middle class to purchase premium grocery private labels. Paper presented at the 3rd Annual University of Johannesburg Faculty of Management International Conference. Broederstroom, 12-14 May.

Benson, J. \& Kinsella, B. 2004. How your supply chain can build or destroy your branding. Encyclopaedia of brands and branding in South Africa. Johannesburg: Affinity Publishing.

Berndt, A. \& Du Toit, G. 2008. An Investigation of the importance of motor vehicle product attributes among generation $Y$ consumers. Paper presented at the 20th Annual South African Institute of Management Sciences Conference. Muldersdrift, 15-17 September.

Best, K. 2006. Design Management: Managing Design Strategy, Process and Implementation. Switzerland: AVA Academia.

Boyle, E. 2007. A process model of brand co-creation: brand management and research implications. Journal of Product and Brand management, 16(2):122-31. [Online] Available from: Emerald:http://www.emeraldinsight.com.innopac.up.ac.za

/Insight/ViewContentServlet/Filename=/Published/EmeraldFullTextArticle/ Pdf/0960160205.pdf [Accessed: 2010-10-26].

Cant, M.C., Strydom, J.W. \& Jooste, C.J. 1999. Essentials of Marketing. Cape Town: Juta.

Chaudhuri, A. \& Holbrook, M. 2001. The chain effects from brand trust and brand effect to brand performance: The role of brand loyalty. Journal of Marketing. 65(2):81-93.

Davis, S. 2002. Brand asset management: how businesses can profit from the power of brand. Journal of Consumer Marketing. 19(4):351-58. 
Dick, A., Jain, A. \& Richardson, P. 1997. How consumers evaluate store brands. Journal of Product and Brand Management. 5(2);18-24.

Du Plessis, F., Bothma, N., Jordaan, Y. \& Van Heerden, N. 2003. Integrated Marketing Communication. New Africa Books: Claremont.

Grace, D. \& O'Cass, A. 2002. Brand associations: looking through the eye of the beholder. Corporate Communication: An International Journal, 15(1):77-91. [Online] Available from: Emerald:http://www.emeraldinsight.com.innopac.up.ac.za/Insight/viewPDF.jsp?Filename= html/Output/Published/EmeraldFullTextArticle/Pdf/2160050202.pdf [Accessed: 2007-04-02].

Handel, G. 1991. Case study in family research. Chapel Hill: University of North Carolina Press.

Hansen, F. \& Christensen, L.B. (eds) 2003. Branding and Advertising. Denmark: Narayana Press.

Henning, E., Van Rensburg, W. \& Smit, B. 2004. Finding your way in qualitative research. Pretoria: Van Schaik.

Jobber, D. 2004. Principles and practice of marketing. London: McGraw-Hill.

Jooste, C.J., Klopper, H.B., Berndt, A. \& Du Plessis, L. 2002. Product management. Claremont: New Africa Books.

Kendall, J. 1999. Axial coding and the Grounded Theory controversy. Western Journal of Nursing Research. 21(6):743-57.

Koekemoer, L. (ed). 2004. Marketing communications. Landsdowne. Juta Academic.

Kotler, P. 2003. Marketing Management. Boston: Prentice-Hall.

Lincoln, Y.S. \& Guba, E.G. 1985. Naturalistic Inquiry. Newbury Park: Sage.

Palmer, A. 2001. Principles of service marketing. Berkshire: McGraw-Hill.

Perrault, W.D \& McCarthy, E.J. 2002. Basic marketing. Boston: Irwin.

Peter, J.P. \& Olson, J.C. 1993. Consumer Behavior and Marketing Strategy. Irwin: Boston. 
Reilly, T. 2004. The power of the brand. Available from: http://www.manufacturing. netind/article/ca37 2317.html [Accessed: 2010-10-13]

Rowley, J. 2003. Market Intelligence and Planning. Bradford: Sage.

Schoenbachler, D., Gordon, G. \& Aurand, T. 2004. Building brand loyalty through individual stock ownership. Journal of Product \& Brand Management. 13(7):488-97.

Singh, V.P., Hansen, K.T. \& Gupta, S. 2005. Modelling preferences for common attributes in multicategory brand choice. Journal of Marketing Research, 11(2):195-209.

Singleton, A. 2004. The corporate brand - a competitive asset. The Encyclopedia of Brands and Branding in South Africa. Johannesburg: Affinity Press.

Siomkos, G., Vasiliadis, C. \& Lathiras, P. 2005. Measuring customer preferences in the winter sports market: The case of Greece. Journal of Targeting, Measurement and Analysis for Marketing. 14(2):129-40.

Stewart, P. 2005. The brand or the bland, why generic customer service is no longer enough! Available from: http://www.allaboutbranding.com/index.lasso?article=383 [Accessed: 2009-11-03]

Strauss, A. \& Corbin, J. 1990. Basics of qualitative research. Newbury Park: Sage.

Strydom, J., Jooste, C. \& Cant, M. 2004. Marketing Management. Cape Town: Juta \& Co.

Sweeney, J.C. \& Soutar, G.N. 2001. Consumer perceived value: the development of a multiple item scale. Journal of Retailing. 77:203-20.

Van der Walt, D.L.R., Cloete, K.E. \& Visser, T. 2008. A Brand Name Makes your Blue Jeans Talk: Why do Students Buy Denims. Paper presented at the 20th Annual South African Institute of Management Sciences Conference. Muldersdrift, 15-17 September.

Vriens, M. \& Ter Hofstede, F. 2000. Linking attributes, benefits and consumer values. Marketing Research. (Fall): 4-10.

Yin, R.K. 1994. Case study research: Design and methods. London: Sage. 